\title{
Study behavior, Study Habits, Achievement Motivations of University Students and Study Advisory Services
}

\author{
Mustafa Ghulam \\ Humboldt Universität zu Berlin, Germany
}

\begin{abstract}
Study Advisory service is a popular helping desk in Universities. From there students can discuss their problems and Questions, which are occurred during the study, which may also cause hurdles in way to continue study with a positive behavior, because to have questions show that somebody is unclear about some matter, and want to know about that. And not to be clear in some matter in Study would may effect negatively on Motivation, study behavior and further on study habits. Because all these factors are connected with each other, if one's affected, it effects automatically on the other factor. Movement of factors is depending on nature of the effect. If the effect is positive then these factors move in positive direction otherwise negative. So a discussion due to some Problem or Question with a study advisory service on right time most probably gives an opportunity to students to solve their Problems with possible suitable solutions or having satisfactory explanation of their ambiguity. It helps them to continue their study with positive Motivation, behavior, furthermore positive study habits. From own Knowledge try to solve these nebulosity is insufficient to get solve these problems properly. So problem remains there, which may effects negatively on the motivations, behavior and Study habits of a student.
\end{abstract}

\section{Introduction}

Performance of education besides other factors depends upon study habits and study behavior of Students. And quality of education is reflected through motivation which is a function of study habits and study behavior of students. Thus to enhance the quality of education, study guidance is necessary to improve the study habits and study behavior motivation of students. We have seen study guidance in universities for higher and further education assume it is real importance, providing immediate and valuable assistance to young peoples. Many of them for the first time in their lives hit first real crises. There they need some Proper guidance to bring some positive change in their life. However, other changes that constantly remind us that there is no way in which study advisors can be complacent: It has been recognized that how many young people (or indeed mature Students) have sought help with long standing and deeply disturbing circumstances. It is not been university life that provoke their first real crisis, but it's been university life which has provided the first heaven from crisis in the family, and there the first real opportunity for help. It is also concern with the way in which universities and colleges provide the helping facilities to come out from the crisis or problematic situation in study. So a study advisory service is also a facility from university or colleges to its students.

Kocher [46] considers study guidance necessary to help the pupil with specific problems like lack of relationship between ability and achievement, due to lack of proper informative study guidance, deficiency in one or several subjects, faulty study habits, and defective methods of learning and poor motivation. For all these problems study guidance service is a facility for students just facilitate them, so that they can recognize their problem and also now how to lose it, how to get rid such kind of hurdles in way to study. Then it would build a connection between study and study advisory service.

\section{Study advisory service}

Every Guidance is definitive, what kind of picture/view of Human a man has, each type of guidance demands another course of conversation, with that the advice seeker can reach on a decision making stage. 'All types of guidance come finally at decision' [29]. Study advisory services offer constructive advisory services and accompany to the students in form of support so that they are enable students to full fill their academic goals. A Study Advisor supports the students with the estimation of his capabilities, talent and to advise them according to their potential in case of different problems during the academic period. Abstractly, study advisory service helps the students not only in case of problems in study, but also in case of difficulties in private life. That makes possible to bring them in a regular position in their Study. The advisor must help to the advice seeker with the recognition of his problem, to search out his goals and supply from information to formulation of alternative variants [29]. All existence and actions are communication, and then the guidance is confirmed in the middle to make some change in the system. Every problem can be partly dissolved not only with communication, but 
also it engaged with the structure of reality. So that's why the problem must be brought to speak out. At Study advisory services the advisor try to bring a student in that position that he tells every thing about his problem. Study Guidance means also organizational guidance, as help to change of institutions, mean motivation to find the decisions for appropriate further educational offers und also mean to arrange a full general meeting and a discussion. Study guidance is a center point with the intermediation between offers and potential of the participant. Student Advisory services is also a place where student get all possible solutions for their Problems and questions while studying. After visiting Study Advisory Service Point students are able to feel that they can achieve their target with their own efforts in Study. They are motivated and come to know that they can deal with the difficulties that they encounter with on way to academic success. It has been taken much time to search for the answer of a question, why some students are more successful then others. It has been assumed different aspects, which have been shown by the successful people's i.e.:

1: They seek the advices of experts, in order to know how to be successful.

2: They can deal with the difficulties that occur on way to success.

3. They experience with their own efforts that success could be achieved in field of study.

4: They feel that success in their studies is useful.

And that thing motivates them to continue their efforts with same motivated behavior.

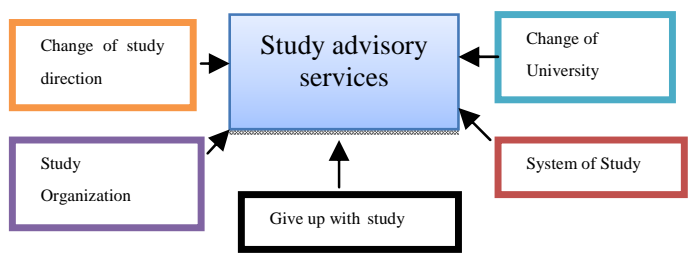

Figure 1. Main problem from the students side at study advisory desk

It is unfortunate that many students consider themselves as they are not good learner and that little can be done to improve their achievement. This faulty belief often remains with individual throughout their lives and limits their goals and aspirations. The problem is not that these students are incapable of being successful learners; they simply have not been informed themselves, how to choose a subject according to their own interests and future Goals, how to handle the complications of the Study system, how to study and learn effectively etc. The end result is lower academic performance. Another term for methods of learning is learning strategies e.g. Learn groups, tutorial etc. Learning strategies are the methods for that students need to acquire concrete information. Higher achieving students use more learning strategies. Study advisory services inform the students towards these effective strategies and method of learning [82]. Before to start the educational career, study advisory is as first line there for help to take a decision to choose a suitable educational offer.

\subsection{Study Advisory Services in Germany and its necessity}

Till winter Semester 2005/06, the German Rectors“ Conference counted 117 universities or equivalent institutions, 158 universities of applied sciences (Fachhochschulen) 58 arts and music colleges, offering 9218 undergraduate courses and 2666 postgraduate and further education programs. This meager number of students, too, can not claim that they have been getting education according to their wishes/capabilities and possessive proficiency in the field of their specialization. Well, there has no major structural change in study guidance since the', New Skills for new future', report in 1998. Study guidance and counseling still consists of two aspects central student advisory services and faculty-based course counseling. The roles and qualifications in guidance and counseling have not been changed since the initial report. There is some need of specific advisory services, which provide the advisory services to those students who have motivation problems in their study behavior, study habits and academic achievement due to several reasons. These days the complexity of life has intensified the need of organized study advisory services. Students need to be motivated through proper study advisory service for developing good academic achievement and adequate preparation to succeed in goals. A Domain-specific self-concept is defined as student's perceptions of their ability to direct and control their motivation, cognition, affect, and behavior in particular domains.

\subsection{Study Behavior}

Study Behavior is the mental readiness to learn. It is organized through experiences, objects and the situations in study. Actually that means with the information and Solutions of the Problems to keep the study behavior for academic goals positive according to Prof. Dr. Thomas Wilmer.

Positive or negative Reaction to a specific object of the study represents the study behavior. Vaidya [77] describe that the special situation is specific for the specific art of the study activities but it depends on the level of mental readiness, it can be positive and also negative. 


\subsection{Study Habits}

According to Good [33] the term study habits as: the students' way of study whether systematic, efficient or inefficient etc." good study habits are perceived to be the determinants of the academic performance. That is why efforts are made to be the determinants of the academic performance. That is why efforts are made to develop and improve study habits of students. University students have to face the emotional causes due to several reasons. They have poor study habits and show poor academic performance motivation. A great deal of evidence is present to show the positive correlation between study habits and academic achievement. And the main purpose of Study guidance is to enable the students to see a clear picture of the information regarding to every aspect of his study system and study problems. Ansari [3] found that study habits and study behavior are both significant variables which determine the academic performance of the students. Rusell and Petrie [64] have cited a research study aimed to find out the relationship between study habits and student behavior and academic performance (cumulative GPA) of university students. Findings of this study indicate a positive correlation between study behavior, study habit and academic achievement. Armstrong [1] declares the study habits as the connection between learning readiness's with an activity in form of a process. Mostly it is for the acknowledgement based on some specific goal and compulsory exercises.

Study Habits has been defined in Dictionary of Education [20] as the Students way of study, it can be effective and ineffective etc. We can say that Study habits are the methods of learning or Acknowledgement, which has been used by a student. The Methods can be both systematic and unsystematic.

A Student can be lazy to do his Class Work, because that work is for him objectless and out of his reach. To avoid such kind of situations the students visit the study advisory services so that they come to know the main reason of their problem or to confirm the choice of their future study.

\subsection{Achievement Motivation}

Well, the standard of education besides other factors depends upon achievement motivation of students. The performance in education is reflected through the academic achievement motivation of students. Theories of achievement motivation, including traditional expectancy-value approaches have been intrapersonal in nature. Some students are dishearten and not motivated due to the complications of the study system and other things, which they cannot solve themselves or with the help of internet or with some friends, they need some proper guidance, they don't know the complications of Module System, Recognition of their Grads, how to learn, subject choice, chose the topic of thesis etc. when they discuss their requests and problems with a study advisor, then they come to know about many possibilities and solutions of their problems. Then they are going to be motivated to do that task in well manners, and that is a big step to success in their study due to the change in their study behavior and study habits and that is all due to study guidance. In case of standard base orientation of an individual the achievement quality will be measured in a way, if one is at that moment better or worse than at an earlier point of time. The motivation of achievementrelated behavior deserves attention, and that comes with proper study guidance. The students with low academic achievement motivation are confronted with some problems, like lack of proper information about study systems, about learn strategies etc. And thereby they should be determined with a new beginning and thereby the motivation of achievement-related behavior obviously attention to study guidance. To improve academic achievement motivation, factors have to be identified affecting these characteristics adversely. Their identification may lead towards remedial measures to identify factors having negative effect on academic achievement motivation. And that negative factors are due to lack of study guidance services.

\section{Link between Study behavior, Study Habits and Achievement Motivation}

According to Vidya [77] behavior as "a condition of readiness for a certain type of activity.” Attitudes held by the individuals may be symbol of complex, stable or unstable, temporary or permanent and superficial or fundamental. Judgments based upon insufficient facts and insufficient information is likely to yield wrong results and thereby biased behavior. Behavior motivation offer great possibilities for successful achievement in studies. They are an important motivator of behavior and affect the achievement of students. And that (Behavior) could be changed by the study guidance. A great deal of research literature provides an evidence for positive link between behavior and achievement motivation. According to crow \& crow [17] a students' behavior towards his work affects his worth wholeness in his activity. And his activities in study are known as his study habits. So these all are connected with each other. Achievement Motivation level effects on study behavior and further it effects on study habits. In some cases Study behavior is not depend on achievement Motivation. If a student is fully interested for his study, and he understand what he do, or what he learn, then he enjoy it and do it further. At that stage he needs not 
to motivate himself, because he does everything in study according to his interests. His behavior follows the strength of his interests for his study and then the strength of behavior has been followed by study habits.

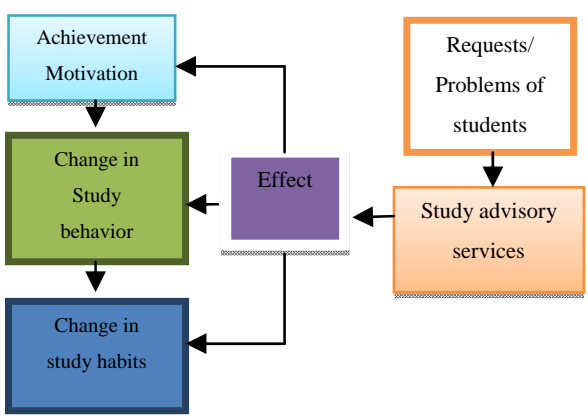

Figure 2. Effects of Study Advisory Services

\section{Problems and Questions of Students, with that they come to Study Advisory services}

The Study behavior is not itself change until for example the study advisory services do something to change it Luthans [51]. Study organizational request or Problems are very common. Mostly students are careless to understand the structure of the study. If they couldn't be able to encounter with study organization, they come to study advisory services to ask how they can organize their study in a better way, so that they could be able to achieve their goal in study. An example as a reason of the problems in study is that the students have to finance their study by themselves, that's why they are not in Time with study organization. At that desk would all these aspects reprocessed, how they can plane and continue their study. Either they have no study plan or mostly they can not study according to plan, then they miss the examination regulations and that is very big problem for them. They feel very unhappy and dissatisfied in their study, in that situation they do contact with study advisory services.

The Students have their own disposition to other peoples, because of examinee objects or thoughts or to abstract concepts. That is the mixture of feelings. Winfield, Bishop and Porter [81].If the students have decided for himself a wrong study direction due to insufficient information, wrong introduction of that study, they would like to change their study direction after a couple of semesters. Because that Study direction doesn't match with their interests and capabilities, that's why their study behavior is not so positive, they feel very uncomfortable in that study subjects, then they come to study advisory services to make sure which study subject would be better for them. Some students do not know if they give up from study or continue it, because they have problem with study behavior. They study unlikely and some of them have no more desire to study. Some students do not like their Lecturers in that way they need some tips from study advisory services.

\subsection{Processing of these Problems/Questions at Study Advisory desk}

Basics of the Problem should be ascertained in the advisory talk. Thereupon it has been tried to find out the causes and source why that study is not according to plan.

Study advisory is required to identify the students' problems, if necessary then to investigate the cause of their problem. It shows the importance of these services. This study is based on the assumption that students with more study problems have poor study behavior and habits and hence poor performance in studies and that's why some are of them come to the decision to change their study direction and also for that reason the study advisory services is appropriate. In case of change a study subject the sureness and reasonability are asked by these services. A study advisor try to know, what kind of information has been used by that student at the time of select a subject, how was his information standard. (Information such like, writing information's, discussions with friends, parents, teachers or professional advisors etc.), and how are the interests of that person. There is a difference between somebody, who study successfully, but eventually has problem: Fear, reading fear, fear from the completion of the degree, if he can or not, fear from future. But it could be some bureaucratic things, which is not understandable for that student or it is just a small crisis or some blocker, which could be overcome by a study advisor. Another reason is that the poor preparation at the time to taking a decision for a subject and inadequately introduction from that study direction. After that the expectations from study are processed, if they are realistic. The interests, the capabilities, preferences, goals, fears, school experiences, "what can I good" are also asked, so that a good recommendation could be given at the time of change and to choose a new study subject.

If someone could not study his current study subject, then it must be examined by the study advisor, what are the alternatives, are there some similar fields of study, which are match with the interests of the students. The study advisor has noticed in discussion with students that they are actually interested for the other fields of study. Such kind of questions from the study advisors to students at time their change of study subjects show to them a clear picture of the study behavior of the students. With that the study advisors are enabling to recommend the students further procedure in study according to their interest and which may effect on their study behavior. 
Mohsin [52] describe that study behavior is not to broach but it is acquire through experiences and available information. And students can get these both things from study advisory services. If it is about the organization of the study, and a student who do not know, how and what should he do now in study, at that point his study behavior is detained, because he don't know how he can move forward in study. In this condition a study advisor process the official study plan and match it with his current condition and try to give him some solution possibilities. In that way move his study behavior normally in a positive direction.

A regular visit of a student to the study advisory show that there is another problem, and then he would intermediated towards the right place. For example, if a student has some psycho problem, and he visit very often study advisory service, then he would referred to the psych. advisory services.

\section{With Study advisory services students are enable to!}

After counseling the student have the feelings that they have more then one solution options. They would enable to think about the solutions choices and feel if they like this or not. The Dissonant Theory and Reinforcement Theory can clarify the changes in study behavior, if the students have such impression that they have some freedom to choose some thing.

They come to know that it is very effective to study if they have plane their semester at good time and start to learn from the right time and regularly. Then it has a big effect on their study behavior. Students get considerable references, information, and the right ways from Study advisory services. They had no idea about this professional and appropriate information before. Although it is help to help themselves. The peoples know accurately what they have to do. If the students try to implement these all important references and Information, their Study behavior will be change. That change will come to existence through study advisory services.

After the individual counseling at study advisory services the students are enable to perceive their own actual interests in study, to compile their own study plan for study, therewith they know about the important things in study, those should be cared by. Kobella [45] write that the acquisition of our study behavior partly is from others. With the awareness about new possibilities, solutions, ways and information, the academic motivation is affected and in that way the study behavior change in that sense that a student is try to busy with more study activities. This happen is mostly positive, because a student learns the things, about them he don't know before his visit to study advisory services. Then it is a possibility that the academic achievement motivation is also moving up. It may a cause to change in Study behavior. So if you get a lot of opportunities and solutions from a study Advisory Service, to change one's thoughts and man may have many ways to deal with Problems. Therefore, these students better deal with their Problems then those students who have never been in the study advisory services. If a student does something with interest, he gets a result in form of success. From that experience he may learn that, to be successful in study is not impossible, just need to be attentive to get solve own Problems in study through proper way. And that proper way is study advisory service. In that way, his motivation level will also be go high and study behavior would be likely connected with study habits. Inasmuch as he pursues his academic activities until its successful completion of his Study. If he does not discuss his Problems with study advisory services, he would may not have much expertise on his Problems and its possible solutions. He could not solve them properly from his own solutions. In a result the problems are there and build up its volumes. That may cause to decrease his motivation in Study which would automatically effect on his study behavior negatively and he may would not likely busy with study activities i.e., his study habits are declining. As a result, he has little success. He should take that opportunity to visit these Advisory services. Then, the situation of his Motivation, behavior and Habits in Study would be positive.

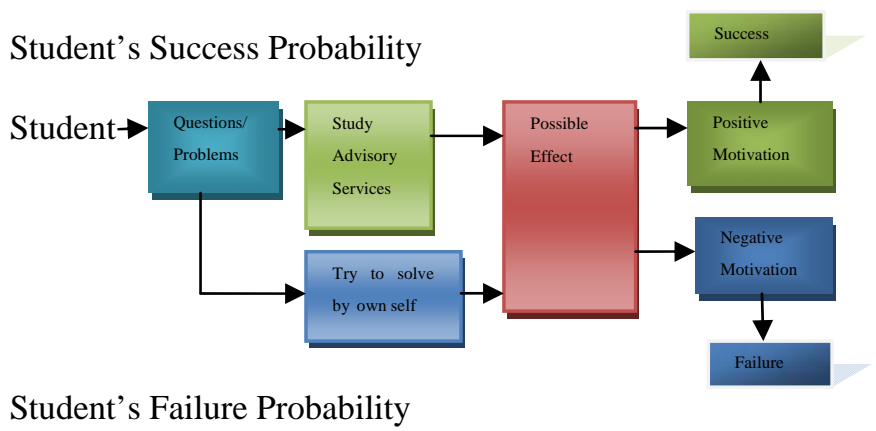

Figure 3: Student's way to solve their Problems during study and its effects

\section{References}

[1] A. J. Onwuegbuzie, J.R. Slate, and R.A. Schwartz, "Role of Study Skills in Graduate Level Educational Research Courses." The Journal of Educational Research, 94(4), 2001, pp. 238-246.

[2] Anastasi, A., Psychological Testing, Macmillan Publishing Co, New York, 1990.

[3] Ansari, Z.A. (1980) 'Study Habits and Attitude of Students', Development and Validation of Questionnaire measures. Islamabad: National Institute of Psychology. 
[4] Armstrong, Study is Hard Work, Harper and Brothers, New York, 1956.

[5] Beratung TU Berlin, "Wo geht's lang?", Studienberatung und Psychologische, Berlin, 2009/2010.

[6] B. Sandhaas, "Studien Bildung Wissenschaft Information”, Studien Bildung Wissenschaft Information, Beratung und Rekrutierung ausländischer Studenten aus Entwicklungsländern, Herausgegeben vom Bildungsminister für Bildung und Wissenschaft, Bonn, 1991.

[7] Balke, Stefan, Ziele in der Lern und Leistungsmotivation, Karoi-Verl. Bornemann, Bielefeld, 1995.

[8] Boehncke Heiner, Vom Referat bis zur Examensarbeit, 2000.

[9] Bohnsack, Ralf, Hauptbegriffe qualitativer Sozialforschung, Opladen [u.a.], Budrich, 2006.

[10] Borg, W.R. and Gall, M.D., Educational Research in Introduction, Longman Inc. New York, 1983.

[11] Braddock, L., Guidance Programme Pages, Retrieved from www.fcps.com, Handbook. 19-6-2001

[12] Buer, F., „Coaching, Supervision und die vielen anderen Formate. Ein Plädoyer für ein friedliches Zusammenspiel“, Organisationsberatung-SupervisionCoaching Volume 12, Number 3, 2005, pp. 278-297.

[13] Bundesanstalt für Arbeit, " Studien- und Berufswahl Informationen und Entscheidungshilfe", Verantwortlich für den Inhalt: $B W$ Bildung und Wissen Verlag und Software GmbH, Herausgeber, Bund-Länder- Kommission für Bildungsplanung und Forschungsförderung (BLK), Nürnburg, 1999.

[14] Bund-Länder-Kommission für Bildungsplanung und Forschungsförderung Geschäftsstelle,“ Kooperative Strukturen an der Schnittstelle ", Schule/Hochschule zur Studien- und Berufswahlvorgabereitung (Heft 126) Bericht, Empfehlungen und Handreichung, Bonn, 2005.

[15] Bundschuh, Konrad, Emotionalität, Lernen und Verhalten, Klinkhardt; Auflage: 1., Aufl., 2003

[16] Christoph O., Student und Studienberatung, Frankfurt am Main, 1974.

[17] Crow, L.D., A. Crow, Educational Psychology, Eurasia Publishing House (Pvt.) Limited, New Delhi, 1989.

[18] Dalton C., M.C. Marguerite, the Art and Practical Wisdom of Student Affairs Leadership, California, 1990.

[19] Der Bildungs- und Ausbildungsauftrag der Hochschule, " Gegenstand der Studienberatung ", Westdeutsche Rektorenkonferenz Dokumente zur Hochschulreform, Göttingen, 1983.
[20] Cater V. G., D. K. Phi, Dictionary of Education, McGraw-Hill, New York, 1973.

[21] Cook, V., Second Language Learning and Language Teaching, 3 ed., New York, 2001.

[22] Ertelt, Schulz, Beratung in Bildung und Beruf, Leonberg, 1997.

[23] Ertelt/ Schulz, Handbuch Beratungskompetenz, Leonberg 2002.

[24] Fontana, D., Psychology of Teachers $\left(3^{r d}\right.$ ed.), Macmillan Press Ltd., London, 1995.

[25] Francis, K.X., McDaniel, M., and Doyle, R.E. Training in Role Communication Skills: Effect of Interpersonal and Academic Skills of High-Risk Freshmen. Journal of College Student Personnel, 1987, pp. 28, 151 156.

[26] Fuhr, Struktur und Dynamik der Berater-KlientBeziehung, in: Krause/ Fittkau/ Fuhr/ Thiel (Hrsg.): Pädagogische Beratung: Grundlagen und Praxisanwendung, München, 2003, pp. 32-50.

[27] Gerhart R., (Gewohnheiten)Statusbericht, Bergische Zentrale ZSB Universität Studien Wuppertal Beratung, Wuppertal, 2007.

[28] Gerda E., "Studienberatung- und Berufsberatung aus der Sicht von Maturanden", Eine Empirische Untersuchung - durchgeführt an der Studien- und Berufsberatung des Kantons Zürich, Frankfurt am Main, Bern, 1982.

[29] Gieseke, Opelt, Ried, Weiterbildungsberatung II, Kaiserslautern, 2004.

[30] Gieseke, W., Lebenslanges Lernen und Emotionen, Bielefeld, 2007.

[31] Gieseke, W., Bedarfsorientierte Angebotsplanung in der Erwachsenenbildung, Bielefeld, 2008.

[32] Gieseke, W., Emotionalität als Bildungs- und Kompetenzmotor im lebenslangen Lernen, In: BWP, 2008.

[33] Good, C.V., Dictionary of Education ( $3^{\text {rd }}$ Ed.), McGraw Hill Book Company, New York, 1973.

[34] Grit M., Studienbegleitung für ausländische Studierende an deutschen Hochschulen, München, 2005.

[35] Günther W., Motivation Verbraucherverhalten, 1973.

[36] Günther W., T. Sabine, F. Martina and D. Catrin, Funktion und Organisation von Studienberatung in der Körperschaft Hochschule, Herausgeben: Universität Rostock, Rostock, Dezember 1999.

[37] Haas, Berufliche Beratung, in: Krause/ Fittkau/ Fuhr/ Thiel (Hrsg.): Pädagogische Beratung, Paderborn, 2003. 
[38] Heckhausen, Heinz, The Anatomy of achievement motivation, Academic Pr., New York [u.a.], 1967.

[39] Hochschulregion Berlin und Brandenburg, Berlin, Winter Semester 2006/07.

[40] Hubner, M.: Coaching als Aufgabe der Erwachsenenbildung. Berlin 2007.

[41] J. Hudesman, B. Avramides, , C. Loveday, A. Wendell, and R. Griemsmann, "Impact of Counseling Style on the Academic Performance of College Students in Special Programmes", Journal of College Student Personnel, 1986, pp. 394 - 399.

[42] Jones, C.D., A.B. Smith, and E.F. Roberts, Book Title, Publisher, Location, Date.

[43] Kemper, M. and R. Klein, Lernberatung. Gestaltung von Lernprozessen in der beruflichen Weiterbildung, Schneider- Vel. Hohengehren, Baltmannsweiler, 1998.

[44] Kell, P., Adult Education @ 21 $1^{\text {st }}$ Century, New York, 2004.

[45] Kobella, T.R., Changing and Measuring Attitudes in the Science Classroom, Research Matters-to the Science Teacher, Publication No. 8901 VA: National Association for Research in Science Teaching, Reston, 1989.

[46] Kochhar, S.K., Educational and Vocational Guidance in Secondary Schools, Sterling Publishers Private Limited, New Delhi, 2000.

[47] König, E., Z. Peter, Theorien der Erziehungswissenscahft, Stuttgart, 2002.

[48] Lippitt, L., Beratung als Prozess. Was Berater und Kunden wissen sollten. Berater und Ratnehmer, Leonberg 1999.

[49] Littlewood, W., Foreign and Second Language Learning, Cambridge University Press, 1984.

[50] Loos, W., Qualität und Leistung von Beratung, Bergisch Gladbach, 2002, pp. 105-132.

[51] Luthans, F., Organizational Behaviour ( $9^{\text {th }}$ Edition), McGraw Hill, New York, 2002.

[52] Mohsin, S.M., Attitude, Concept Formation and Change, Wiley Eastern Limited, New Delhi, 1990.

[53] Müller, Weiterbildungsberatung: Qualitative Analyse von Interaktions- und Prozessverläufen situatuver und biografieorientierter Weiterbildungsgespräche, Berlin, 2005.

[55] Müller, J., Coaching, Biografie und Interaktion. Eine qualitative Studie zum Coach in Ausbildung, Opladen, 2006.

[56] Nestmann, Beratungsmethoden und Beratungsbeziehung, in: Nestmann/ Engel/ Sickendiek
(Hrsg.): Das Handbuch der Beratung, Band 2, Ansätze, Methoden und Felder, Tübingen, 2004 pp. 791-795.

[57] Pätzold, H., Lernberatung in der Erwachsenenbildung, Baltmannsweiler, 2004.

[58] Pohlmann, M. and Ziellmann, T. (Hrsg.), Beratung und Weiterbildung, Fallstudien, Aufgaben und Lösungen, München, 2006.

[59] Rana, R., Counselling Students, London, 2000.

[60] Rauen, C., Qualität von Coaching-Weiterbildungen. In: Strikker, F (Hrsg.).: Coaching im 21.Jahrhundert : kritische Bilanz und zukünftige Herausforderungen in Wissenschaft und Praxis, Augsburg, 2007, pp. 28-39.

[61] Rauen, C. (Hrsg.), Coaching-Tools. Erfolgreiche Coaches präsentieren 60 Interventionsstrategien ais ihrerCoaching-Praxis, Bonn, 2007.

[62] Rauen, C. (Hrsg.), Coaching-Tools II. Erfolgreiche Coaches präsentieren 60 Interventionsstrategien ais ihrerCoaching-Praxis, Bonn, 2007.

[63] Rohs, M., Käpplinger, B. (Hrsg.), Lernberatung in der beruflich-betrieblichen Bildung. Konzepte und Praxisbeispiele für die Umsetzung, Münster, 2004.

[64] Russel, R.K. and Petrie, T.A. (1992) 'Academic Adjustment of College Students: Assesment and Counselling' in Steven D. Brown, Robert W. Lent. Handbook of Counseling Psychology.

[65] Sanders, Die Beziehung zwischen Ratsuchenden und Berater, in: Nestmann/ Engel/Sickendiek (Hrsg.): Das Handbuch der Beratung. Band 2. Ansätze, Methoden und Felder, Tübingen, 2004, pp. 797-807.

[66] S. Kühl, "Die nur fast gelingende Schließung des Personalentwicklungszyklus“, OrganisationsberatungSupervision-Coaching, 15, 2008, pp. 137-155.

[67] Schiersmann and Remmele, Beratungsfelder in der Weiterbildung: eine empirische Bestandsaufnahme, Baltmannsweiler, 2004.

[68] Schermer, Franz J. Methoden der Verhaltensänderung, Stuttgart, 2006.

[69] Schiersmann and Thiel, Beratung in der Weiterbildung, in: Nestmann/ Engel/ Sickendiek (Hrsg.): Das Handbuch der Beratung. Band 2. Ansätze, Methoden und Felder, Tübingen, 2004.

[70] Schreyögg, A., Coaching. In: Nestmann, F./ Engel, F./ Sickendiek, U. (Hrsg.): Das Handbuch der Beratung. Bd. 2 Ansätze, Methoden und Felder. Tübingen, 2004, pp. 947-957.

[71] Schreyögg, A. and Schmidt-Lellek, C. J. (Hrsg.), Konzepte des Coaching, Wiesbaden, 2007.

[72] Schuster H.J. and L. Peter, Büro für Studienberatung der Universität des Saarlandes Bericht über die Evaluation von Beratungseffekten des Modellversuches 
einer integrierten Studienberatung der Universität des Saarlandes, Saar Brücke, April 1979.

[73] Shertzer, B. and Shelly C. S., Fundamentals of Guidance, Houghton Mifflin Company, Boston,1976.

[74] Simpson, R. D. and others, Research on the Affective Dimension of Science Learning. In Dorothy L. Gabel. (1994). Handbook of Research on Science Teaching and Learning. A Project of the National Science Teachers Association, 1994

[75] Stipek, Deborah J., Motivation to Learn, Allyn and Bacon, Micigan,1993.

[76] Thiel, R., Berufs- und Karriereberatung in Deutschland, in: Nestmann/ Engel/ Sickendiek (Hrsg.): Thiel Das Handbuch der Beratung. Band 2. Ansätze, Methoden und Felder, Tübingen, 2004.

[77] Vaidya, N., The Impact Science Teaching, Oxford \& IBH Publishing Co., New Delhi, 1989.

[78] Wigfield, Allan, Development of achievement motivation, Acad. Press, San Diego, 2002.

[79] Wilkins, D.A., Linguistics in Language Teaching, The English Teaching Book Society, U.K., 1972.

[80] Williams, N. and Burden, R.L., Psychology for Language Teachers: A social Constructivist Approach, University Press, Cambridge, 1997.

[81] Winfield, P.W., R. Bishop, and K. Porter, Core Management for HR Students and Practitioners, Licensing Agency Ltd., London, 2001.

[82] Zimmermann, Barry J. [Hrsg], Self regulated learning and academic achievement, Springer [u.a.], New York, 1989. 